\title{
Usury and the problem of exchange under capitalism: a late-nineteenth-century debate on economic rationality
}

Mischa Suter University of Basel, mischa.suter@unibas.ch

Note to readers: this is the penultimate manuscript version of the essay. For reference, please consult the published version: Suter, Mischa: "Usury and the problem of exchange under capitalism: a late-nineteenth.-century debate on economic rationality", in: Social History42(2017) Nr. 4, S. 501-523.

ABSTRACT

Examining the ambiguous concept of usury, this article retraces political battles over the epistemic framings of the everyday economy in the nineteenth century. It takes a comparative approach to the legal and economic debates on usury in the Habsburg and the German empires in the wake of the economic crisis of the late 1870 s, when new laws against usury were introduced. In the respective debates, diverging political interests and class attitudes pitted different conceptualisations of economic exchange against each other. At stake were the diverse forms of commensuration and valuation scales in received credit practices. The new legislation on usury centred on the notion of a usurer's victim who supposedly was incapable of rational economic action and thus in need of civilisation. By way of conclusion, this article relates the story of nineteenth-century usury legislation to current debates among historians on capitalism and the emergence of the economy as a bounded entity. It argues for more analytical attention to historical conflicts over modes of exchange as they came to the fore in the debates on usury, and discusses the implications of this perspective for the history of economic liberalism.

KEYWORDS: usury; money; debt; nineteenth-century Germany; social conflict; imperial politics; economic crises 
Usury is an ambiguous concept, uneasily pairing economy and morality. Today, we might associate usury with the ban on interest in the Middle Ages, which drew the line between an economy of salvation and the world of trade. ${ }^{1}$ Alternatively, as has been argued by Albert Hirschman, the history of the French and English term 'interest' shows how 'interest' gradually left the sphere of finance and its negative association with usury, ultimately coming to signify rational, calculated, goal-oriented action as such. ${ }^{2}$ In the German of the early modern period, usury was a multi-faceted, politically charged concept that brought together a number of illegitimate market practices, such as forestalling, hoarding, and profiteering. However, it gradually disappeared after 1848 with the decline of the early modern politics of provision, only to suddenly come up again in the urban consumer protests of First World War. ${ }^{3}$ Usury thus appears as something untimely, far removed from the cycles of a modern economy. Yet, in the last quarter of the nineteenth century usury had a specific meaning, and this essay deals with it and it alone: it signified a discourse of order on the relationship between creditor and debtor and a diagnosis of a perceived crisis. In the concluding decades of the nineteenth century, usury was made into an object of legal reasoning, economic theory, social-scientific expertise, and antiSemitic mobilisation. This was a new situation, because by the middle of the nineteenth century, all of the German-speaking states had repealed existing laws on usury, which had limited the permitted rates of interest on credit. Yet only about ten years later, they all reintroduced new usury laws: first in 1877 in the eastern parts of the Habsburg Empire, then in some Swiss cantons, in 1880 in the German Empire, and in 1881 for the whole Habsburg Empire. In 1893, the juridical scope of the concept of usury was expanded, and the laws in the German Empire revised accordingly.

These new laws on usury reframed the problem. No longer was usury defined by a legal restriction on interest rates. Rather, it was defined by the creditor's exploitation of a debtor's distress, economic inexperience, or carelessness. Whether an act constituted usury was thus no longer determined by an objective measure, but by the subjective situation of the victim. The criterion was the debtor's economic behaviour. The economist and social theorist Lorenz von Stein succinctly summed up this new conception of usury in 1880 by calling usury a 'debt that reproduces itself' ('eine Schuld, die sich selbst gebiert'). This 'debt that reproduces itself' led a debtor, who was forced to take up ever-new debt, to lose his 'means for economical calculation', or, his 'business sense'. ${ }^{4}$ Lorenz von Stein portrayed usury as a vicious circle spiralling around a problem of economic rationality, that is, the 'business sense' that the debtor stood to lose. 
In what follows, I trace the transformation of usury as a discourse of order and a diagnosis of crisis. I am interested in an aspect of the history of economic rationality that appears in the conflicting conceptions of economic exchange that were at stake in the debates on usury. Economic rationality is treated as a native category here; that is, I look at how academic experts, politicians, bureaucracies, journalists, and everyday creditors and debtors framed the economic as a problem of temporal metrics and subject orientation. My argument is in dialogue with historical research on the epistemic production of the economic, and specifically, on the emergence of valuation scales, statistical aggregates, informational infrastructures, and conceptual foundations, which became salient in various fields after the $1870 \mathrm{~s}$ - for example, in the debates on the limits of finance and futures trading, in the global arrangement of day time, in the separation of national economy and world economy, or in the institution of the gold standard. ${ }^{5}$

When late nineteenth-century experts debated the problem of usury, they pitted different conceptualisations of economic exchange against each other. Opposing political interests and class attitudes came to the fore when, for example, agrarian capitalists expressed fears of a loss of control over the rural population by a perceived spread of usury, or when middle-class social reformers argued for the modernization of credit markets, or when bourgeois politicians corralled the discourse of usury into the sphere of consumption, in order to suppress demands made by social democrats, who, in turn, took up the discourse of usury to argue for higher wages. Such political battles were imbricated with changing epistemic framings of the everyday economy, and I thus argue for a heightened awareness of the interlacement of socio-structural contradictions and epistemic tensions. Importantly, though not always, the problem of usury was framed as a problem of an imperial periphery, where different currencies, measures of value, and received practices of exchange collided with requirements ushered in from the imperial centre, leading to ever-new contradictions. By recovering discourses in the imperial centre that grappled with exchange practices in the periphery I do not wish to suggest a binary division between centre and periphery; rather, one might speak of 'central peripheries', because the periphery here was a site of encounter where the form of economic rationality was given shape. ${ }^{6}$ Accordingly, my perspective is informed by historical studies of colonial economies such as that of Manu Goswami, who shows how British imperial projects thrust aside Indian currencies and exchange practices thereby shaping the colonial economy as a distinct spatio-temporal object, and of Ritu Birla, who depicts how British imperialists suppressed what she terms 'vernacular capitalism'. In the German-speaking discourse of usury, however, notions of 'backward' underclasses and 
anti-Semitic demonization of existing exchange relations stretched over the semi-colonized East and the non-colonial centre alike. Rather than asking whether usury really existed or not, the method I follow is to reconstruct comparatively these thematisations of usury through which which, by way of social conflict, the economy as an object of knowledge and economic rationality took shape as a distinct form of orientation.

\section{Transformations of a diagnosis of crisis}

It was not only the reintroduction of usury laws that took place under the auspices of crisis; their repeal was also itself the product of crisis. Ironically, the rhetoric of a state of emergency motivated both their repeal as well as their renewed adoption. In the fall of 1857 , as a wave of bankruptcies caused by the 'effects of the American economic crisis' were emanating from the port city of Hamburg and spreading general 'mistrust and lack of credit' in the German business world, the Prussian State Ministry initiated the temporary repeal of interest limits for certain types of loans in order to revive the credit market. ${ }^{8}$ These measures were renewed during the 1866 Austro-Prussian War, and in 1867 usury laws were definitively abolished in the North German Confederation followed by the Habsburg Empire in $1868 .{ }^{9}$ Drawing on a tradition of political-economic debate on interest in works like Jeremy Bentham's Defence of Usury, some German economists commended the deregulation of interest in the name of free trade, competition, and innovation. ${ }^{10}$ Bentham had positioned himself against Adam Smith, who had argued that unregulated interest rates would bring about a situation in which 'prodigals and projectors' fraught with risk would come to outnumber all other borrowers in the credit market. ${ }^{11}$ However, it was not matters of principle but pragmatic interventions that laid the foundations for the spread of the idea that money, 'like every other commodity, is subject to the law of competition of supply and demand according to its respective price', as a Habsburg minister put it in $1858 .^{12}$ All this changed in the wake of the Panic of 1873 and the cascade of crises that followed it. The Long Depression was a protracted process of deflation, shrinking growth and sales crises. ${ }^{13}$ Academic experts and politicians came to 'reform economic law' with correctives for liberalism, as one contemporary formulated it. ${ }^{14}$ Economists accepted the laws of free competition, but they believed that these laws were only in full force in certain spheres, such as the 'world market' or the 'stock exchange'. ${ }^{15}$ Economy was thus conceived of as a multi-level 
system in which everyday life seemed backward: 'in the lowest strata of trade', 'the parochial relations that correspond to the lower levels of culture' would retain their validity. Small-time borrowers would not take credit for productive purposes, but in states of 'bitter need', and would be unable to consider the consequences due to their 'lack of education'. Drawing on classics like the works of Wilhelm Roscher, it was consensus among economists that 'the doctrines of political economy' could only be applied to 'civilized conditions', and thus that applying the principals of free competition in countries with a 'lower level of development' was out of the question. ${ }^{16}$ Protection and education in everyday economic relations were concerns whose urgency was underscored by the declaration of a state of emergency. In the Habsburg Reichsrat, Galician representatives drew a picture of a region ravaged by usury, and an economist from Czernowitz seconded them when speaking of Bukovina: 'We have no organic society here, no people, no nation', just peasants 'whose depressed being and slavishly subservient comportment' would be immediately apparent to every foreign visitor. ${ }^{17}$ In 1879 , after Upper Silesia experienced crop failures and flooding, the Prussian Landtag too debated declaring a 'state of emergency' in this region near the border with Russia; during the debate, the minister of finance reported that usury had 'spun up' the 'in itself poor and harried population' with an 'indestructible net'. 18

The rhetoric of the state of emergency called up questions of imperial power, control, and the need for civilising measures: imperial experts expressed fears about the dynamics of exchange relations on the periphery. They debated the 'problem of freedom' in a post-manorial society, a problem that transnational historians have researched with particular focus on labour relations and race in the 'protectorates', the German east, and the 'inner mission'. ${ }^{19}$ It is useful to extend such findings on labour relations to exchange relations. Thus some aspects of the politicaleconomic aftermath of the Panic of 1873, which have been debated by historians ever since the publication of Hans Rosenberg's Große Depression und Bismarckzeit, might be revisited albeit from a different perspective. ${ }^{20}$ By treating the problem of economic rationality, the question of liberalism's decline ceases to occupy centre stage. Rather, I seek to illuminate proponents' projected reconfigurations of liberalism, which aimed to restitute the market as a regime of truth through the use of protection, education, and state intervention. Such a perspective is tangential to, yet different from, a line of thought informed by Critical Theory, according to which the very form of capitalism - a mode of domination whose social practices are themselves founded in abstractions - occasioned distorted understandings of social relations, or, in other words, 
fetishistic world views. ${ }^{21}$ Thus, finance capital was taken as the cause of crises, circulation was seen as the centre of exploitation, and anonymous forces were personalized and projected onto the image of the Jewish manipulator. This is a strong thesis, deductively arguing from a vantage point of capitalism's systemic characteristics. In contradistinction, however, I want to analyse something quite specific, namely, the constitutive elements of unpredictability, lack of transparency, and disjointed temporality that, in the eyes of the diagnosticians of crisis, had to be combated in the fight against usury. Discourses on backwardness, understood as 'a sense of lag and consciousness of lack', were crucial for usury as diagnosis of crisis. ${ }^{22}$ What is more, academic experts of the time did not exclusively - and not even primarily - focus on finance, but rather on received practices of borrowing and calculation. One historian has spoken of the 'double helix of economic anti-Semitism' in order to describe how Jews were simultaneously depicted as filthy paupers and as plutocratic conspirators; in both cases, Jews were seen as marginal, parasitic, and powerful. In the discourse on usury, the pauperized underside of this double helix was, in a sense, dominant. ${ }^{23}$

\section{A new concept of usury in the Habsburg Empire}

In November 1874, a trial began in Vienna that fuelled the debates on usury laws in the eastern parts of the Empire. Getzel Wilkenfelde stood before the judge, a man in his mid-50s from Galicia who was described in the press as illiterate: 'he can only count'. ${ }^{24}$ During the trial, which ended in the summer of 1875 with a sentence of three years incarceration, Wilkenfelde's supposed crimes were viewed in the context of the debates on usury in the Galician Landtag. ${ }^{25}$ Together with his two sons, Wilkenfelde was accused of engaging in fraudulent loan practices in Vienna. However, this was not his first appearance in the newspapers: in their reports on earlier trials in which he was either plaintiff or witness, the Viennese papers had described Wilkenfelde, who wore traditional Polish-Jewish clothing and spoke in dialect, as a 'living caricature'. ${ }^{26}$ During the trial against Wilkenfelde, the alleged usurer was depicted in a derisive manner rather than as a powerful manipulator. Nevertheless, press coverage depicted the case as exemplary for the state of things in the Empire's east: Wilkenfelde was 'the unspeakably awful embodiment of unspeakably awful conditions'. ${ }^{27}$ This set the stage for debates in the Reichsrat that December, which were initiated by a query from the conservative Polish representative from Galicia, Andrzej Rydzowski. ${ }^{28}$ In the ensuing parliamentary debate and up until the passage of the 'Law 
on Remedies against Dishonest Actions in Credit Transactions' for Galicia in 1877, the concept of usury congealed into an interpretive framework whose constituent elements were nevertheless diverse. During the debate, the right attacked the government and linked the need to protect farmers to an allegedly rapacious 'finance liberalism' ${ }^{29}$ However, the bill was also well received by liberals because it did not set a limit on interest rates; rather, it was modelled on analogous parts of laws on commerce protections for minors. ${ }^{30}$ The law made the criterion for determining whether an action was usury the 'mental incapacity' of the person usured, a notion that encompassed 'inexperience in business matters', a temporary financial 'hardship', or a 'discomposure of the mind' as a result of alcohol consumption. ${ }^{31}$ Thus, the law did not denote a sharp conceptual turn: as early as 1866, similar clauses had been formulated that reflected a longstanding view that credit transactions that exploited the borrower's 'inexperience or hardship' were to be prohibited. ${ }^{32}$ However, in the 1870 s, the common sense idea that certain market actors should be protected was articulated in a different context and was more politically charged than before.

Structural changes in the property and credit markets in Galicia were one factor that fed fears about usury. After the abolition of serfdom in 1848, Jewish creditors replaced manorial lords as intermediaries. In 1867, restrictions on Jews in the real estate markets were repealed. Making up about $13 \%$ of the population in eastern Galicia, Jews entered the agricultural trade - without, however, ever attaining a dominant position - and became increasingly visible as noninstitutional creditors in the second half of the 1870s. ${ }^{33}$ Added to that was a wave of forced sales. ${ }^{34}$ There was an outcry in the Reichsrat when representative Rydzowski released the numbers during a debate on usury legislation: the number of forced sales would increase every year by $150 \%$, and their number in 1874 was $525 \%$ greater than in 1867 , the last year before the repeal of usury laws. ${ }^{35}$ In contrast, the liberal representative Max Menger put these numbers in a different context, referring to the fact that, relative to the number of property owners and the area of the crown land, Galicia had seen less forced sales than other regions. He claimed that Galicia was going through 'necessary, natural processes' that were slowly allowing mid-sized and large farms to sprout up after the abolition of the manor system. ${ }^{36}$ Additionally, liberal representatives argued that the Polish landed aristocracy also demanded high interest rates, not just Jewish creditors. ${ }^{37}$ An accepted fact was agriculture's heightened need for capital, which was caused by the fact that estates could now be divided and by the development of new methods of harvest. The forced sales were often undertaken by banks, and after 1880 primarily so. ${ }^{38}$ Nevertheless, 
experts advocated for the expansion of institutional credit in the territory, which was plagued by a lack of capital. ${ }^{39}$ Galicia ultimately became dependent on superregional financial flows. This was coupled with bolstered mechanisms of exclusion, first and foremost directed against the intermediary role of Jews. ${ }^{40}$ Credit unions, whose implementation experts recommended, played a decisive role in the exclusion of Jews and the 'ethnicisation of social relations ${ }^{4}{ }^{41}$ As contact zones for credit transactions, the taverns in particular stirred anxieties. Taverns were associated with Jews and dubious contracts were attributed to alcohol consumption. ${ }^{42}$ Thus, the 1877 usury law for Galicia was passed together with a law to combat drunkenness. The anti-Semitically loaded alcohol question and the usury law overlapped: both aimed to draw cultural boundaries and both honed in on the problem of insufficient rationality. Ranking Viennese civil servants initially claimed that the new usury law was only suitable for the "wholly unique circumstances in Galicia' and that it could not be applied elsewhere. ${ }^{43}$ Yet not long thereafter it was indeed applied elsewhere, as in 1881 the law was expanded to the whole of Austria. The reason for this was that the results of the debate corresponded well with widely held wishes for educating responsible, consciously economic subjects, pursued particularly by liberals. ${ }^{44}$

\section{From the periphery to the centre: the debate in the German Empire}

The debate in the German Empire shared two features with the debate in the Habsburg Empire. First, it was also stoked by a crisis situation on the periphery, and second, it was initiated by political forces on the right, who nevertheless were pushing an agenda that was spread across the political spectrum. During the state of emergency in Upper Silesia mentioned above, crop failures and poverty were debated as issues of power in local exchange relations. Representatives claimed that smaller farmers would 'fall into a state of dependency on their creditors', who would in turn treat them 'almost as slaves'. ${ }^{45}$ They believed that the Polish speaking population was characterized by a 'lack of business sense [and] thriftiness, slavishly frivolous joyousness, and unreliability' ${ }^{46}$ A district administrator from Ratibor proposed setting up a 'dictatorship' for a period of 10 years and subjecting the population to 'a strict, yet good-willed regime'. ${ }^{47}$ Such ideas from the circles of the large landowners recalled the Junkers' loss of power during the abolition of serfdom. The Junker Hans Hugo von Kleist-Retzow, who took the decisive initiative in the Reichstag on the matter, related farmers' dependency on debts to concerns about a loss of 
control over the rural population: 'We used to have suzerainty and homage; they were based on fiefs, on fidelity and trust, above and below [...].' He continued by claiming that today, 'the powerful, egoistic domination of capital without moral foundations' ruled over the people. ${ }^{48}$ In this conservative attack, Kleist-Retzow exploited the whole rhetorical arsenal of plutocracy and senselessly calculating abstraction that had become a widely spread tropes after the Panic of $1873 .{ }^{49}$ For the right, the usury debate provided the foundations for an alliance between the Catholic Centre Party and the Conservatives by enabling both to draw on popular arguments of the anti-Semites. ${ }^{50}$ However, while Centre representatives wanted to place limits on interest rates and restrict the right to sign bills of exchange to merchants, the proposals of the Conservatives were not geared towards such policies. ${ }^{51}$ According to one contemporary, by modelling itself on the Galician law and making the 'exploitation' of hardship, carelessness, or inexperience into the criteria for usury, the Conservative proposal was 'ten times as liberal' as the laws of liberal governments in other countries. ${ }^{52}$ The semantics of 'exploitation' brought a concept into the debate that made exceptional, radically unequal relations and moral outrage into objects of juridical discretion. With this came a turn away from legal positivism and a demand for the introduction of ethical values into the economy. The newly discovered malleability of society that found its expression in protective tariffs and social insurance proved itself adaptable to classic postulates of education. ${ }^{53}$ In a treatise on usury and pawning, Gustav Schmoller, the most influential member of the historical school of economics, claimed that economic institutions were malleable entities - 'just forms' - that were supposed to 'serve higher purposes, above all the education of society'. ${ }^{54}$ For all practical purposes, the usury law was not aimed at the world of finance: expert opinions from the regional branches of the Reichsbank as well as hundreds of letters from banks, savings banks, and credit unions had warned against placing restrictions on credit transactions and other financial instruments. The debate on usury was carried out in sweeping terms, often drawing on anti-Semitic discourses that articulated the problem of debt as part of the 'Jewish question' ${ }^{55}$ However, in doing so, it tended to compartmentalize the issue. 'Exploitation' was accordingly defined as a set of asymmetrical power relations and distortions revolving around a subject who proved to be unfit for the realities of the market. In the German debate, officers and students were repeatedly referenced: ${ }^{56}$ Young men who were bound to an economy of honour and who were thus seen as being susceptible to falling victim to nefarious usurers, and, by extension, to destroying their families' savings and reputation. ${ }^{57}$ Due to the fact that they were only partially integrated in market relations and thus occupied a special role in 
commercial society, it was believed that these persons should be protected. According to experts, another dangerous aspect of usury was the fact that it brought together heterogeneous frames of reference. This showed itself not only in the supposedly superior intelligence of the usurer, but above all in the opaque exchange relations of everyday economic life.

\section{Peripheral monies and exchange practices}

What constituted these relations that so bothered academic experts that they thought they should be done away with? As historians of empires have shown, trade practices on the periphery have never been separate from developments in the centre. ${ }^{58}$ Rather than speak of whole systems like 'the market economy' or 'local society', it seems more appropriate to research smaller, more specific interfaces, like the various valuation scales in use at the time. ${ }^{59}$ On the periphery, in places like Upper Silesia or Galicia, various forms of currency (paper, coins, metals) were in circulation, and each had specific, yet variable rates of conversion; different metrics for calculation were in use (the decimal system being just one); debts were laid down in a number of different contract forms and systems of notation; and their payment became due in different rhythms. As economic anthropologists have shown, in inconstant heterogeneous markets, marginal yields through arbitrage rather than the exchange of equivalents are the norm. Correspondences were produced by the constant conversion of distinct forms of value rather than pre-existing it. Part and parcel of this mode of exchange was the use of bills of exchange which circulated as surrogates for money and were subject to a heightened compulsion to pay. Another aspect of peripheral economies was the practice of allowing debts to stand beyond their due date. Such elastic payment dates guaranteed the sort of flexibility necessary for a precarious economy, but they also gave occasion for conflict. Just as common were special forms of billing, such as the practice of taking a kreutzer per owed guilder as interest on short-term loans (which adds up to an annual rate of about $52 \%) .{ }^{60}$ Conventions like taking a bushel of wheat as interest in the fall catered to the cyclical need for money in agriculture. ${ }^{61}$ Instalment payments that were set up in such a way that going into forbearance made the entire debt immediately due were used for mortgages as well as for products like sewing machines. This sped up the tempo of the rural economy's seasonal rhythms. ${ }^{62}$ Local exchange relations were not autochthonous or traditional, however. Rather, received practices were subject to constant change. The standards of commensuration underwent shifts with the institution of new national and imperial currencies. ${ }^{63}$ 
Implemented in the German Empire in 1873, the gold standard was the object of attacks by export-oriented big farmers. Because silver coins were gathered up and sold in the process of shifting to the gold standard, the price of silver sank. This worsened the terms of trade with Russian grain exporters, because Russia had kept its silver currency and could thus sell its grain on the world market for less. ${ }^{64}$ On the local level, the new standards of commensuration caused confusion as new currencies with their own values and metrics overlapped with old ones. Civil servants in Upper Silesia reported that the 'most dangerous and violent of these intelligent interest usurers', the 'Semites', monopolized the new Reichsbank money. ${ }^{65}$

This plurality of modes of exchange increasingly became the object of criticism. Intermediaries attracted the distrust of state institutions, and Jews - in their alleged role as brokers, traders, peddlers, emigration agents, innkeepers, and money lenders - came to be seen as fundamentally suspicious. ${ }^{66}$ Civil servants both at the centre and on the periphery used these antiSemitic associations, as a case from the Habsburg Empire amply demonstrates. In 1876, Anton Rawro, a wealthy farmer from the Sambor district in Galicia, petitioned the emperor for relief because his accusation against a Jewish creditor had failed in court. According to the report of the Ministry of Justice, Rawro had arranged a period of forbearance with the creditor. In the process, a promissory note was made out for 300 guilders of the old Viennese currency, which the rural population were still using in their calculations, or 120 guilders of the new Austrian currency. The illiterate farmer symbolically signed the note by touching the pen in the hand of a witness who actually signed the note, an 'unknown Israelite', as the report states. ${ }^{67}$ The Ministry of Justice recommended that Rawro's petition be accepted. Symbolic acts like the almost magical touching of a pen, divergent forms of calculation like the old Viennese and the new Austrian currencies, selectively remembered, unidentified witnesses like the 'unknown Israelite' all appeared as elements in a conspiracy that the helpless farmer had walked right into.

Jews were depicted here as manipulators in a backwards world. This discourse was less concerned with the abstract notion of finance in general and more with the desire to bring order to a situation that was viewed as being plagued with opacity. However, the provinces sent news that complicated this view. A letter from Upper Silesia found that general poverty and a lack of capital were responsible for the hardships there, and not usury. ${ }^{68}$ Also, it was not only personal credit that made up the fabric of local exchange relations, as formalized credit relations played a role too. Formalized relations had a force that endangered their non-formal surroundings. From the perspective of the everyday practices of the province, formalities like maintaining a bank 
account, taking somebody to court, or mobilizing a legal document were not givens, but concrete, tiresome, and risky. ${ }^{69}$ Thus, complaints from Galicia viewed bank institutions and their formalities more as part of the problem than as part of the solution. For instance, in 1868 Galician elites founded the so-called 'Rustikal-Bank' ['Rustic Bank'], which gave farmers seeking credit promissory notes with variable rates of exchange rather than cash. Letters of protest soon reached Vienna complaining that the 'Rustikal-Bank' was more of a usurer than the private lenders. ${ }^{70} \mathrm{~A}$ petition from thirteen districts in Lemberg described the 'public usury' of the bank institutes as a bureaucratic nightmare. A man seeking credit was left to fend for himself against the grueling formalities of the bank, was made to pay hefty fees, and in the end received notes of shifting value instead of cash, and was forced to pay even more fees if he fell into forbearance. ${ }^{71}$

Under such circumstances, money was only partially fungible. The problems of conversion are made clear by the example of the so-called cattle lease, a complex form of ownership and credit that arose out of precarious economic conditions. With the cattle lease, a merchant gave a farmer a young cow, who raised it until it had one or two calves. At the end, the cow and calves were sold, the original price of the cow subtracted from the sum, and the remaining profits split two ways. In the meantime, the farmer had the cow's milk, but he had to supply the feed. If the cow died, he had to pay for it out of pocket. One case from Alsace tells how a farmer loaned a young cow for 50 marks, held it until it had two calves, and, after four years, sold all three animals. In the end, the cow sold for 300 marks, the first calf for 150, and the second for 50. The sum of 500 marks split two ways brought the farmer 250 marks. A representative from an agricultural association calculated that if the farmer had borrowed the original 50 marks at 5\% interest, he would have only owed 60 marks and 79 cents after four years and had the 500 marks all for himself. ${ }^{72}$ Observers found that the cattle lease was a widespread practice in the southwest and west of the German Empire, where the custom of partible inheritance meant that there were many independent farmers with small properties. The practice reached its high point in $1879 .{ }^{73}$ Yet statistics were hard to come by. Observers remarked that the farmers were largely silent on these issues and believed this had to do with their social aspirations: for reasons of prestige, farmers wanted to have as many cows in their stalls as possible. They would thus conceal the truth of their ownership out of shame and, in their mistrust against other farmers, be quickly taken advantage of. ${ }^{74}$ 'Added to that', an agricultural expert remarked, was the fact 'that, in general, farmers have greater trust in merchants than they do in their own' ${ }^{75}$ In attributing farmers with a 'greater trust' towards merchants, what was at issue were relations between 
farmers and merchants, Jewish and non-Jewish, in which different ideas about what constituted correct economic behaviour were also in play. Thus, these relations were more complex than anti-Semitic publicists and officials made them out to be, a point I will come back to below. ${ }^{76}$

\section{A reordering of exchange relations}

While imperial constellations certainly gave significant impulses to the debates on usury, some of the exchange practices discussed above should make it clear that the discourse of usury cannot wholly be ascribed to the conditions of the periphery. A look at Switzerland, where new usury laws were also put on the books, might serve to illustrate this point. In the spring of 1879 , shortly after the passage of the usury law for Galicia, the Canton Solothurn in northwest Switzerland not exactly a semi-colonial territory - followed with its own law. ${ }^{77}$ As in Zurich and Basel, usury was discussed in association with peddling and pawning, that is, exchange relations in the sphere of consumption, not rural mortgages. ${ }^{78}$ As the Swiss examples show, the notions of order that found their expression in the discourse of usury could be adapted to diverse contexts, and could always be expanded upon. Its frequency as a topic of discussion stood in sharp contrast to the actual number of court cases. After the passage of the usury law in Germany in 1880, the number of accusations was insignificant, the number of convictions even smaller. One statistical source counted, for the whole empire, 261 accusations and 98 convictions in 1882 and 131 accusations and 37 convictions in $1885 .{ }^{79}$ These low numbers notwithstanding, during the 1880 s usury became an object of debate in the social sciences like never before: in 1887, the Verein für Socialpolitik [Association for Social Policy] - the German Empire's most prestigious socialscientific institution - published a study that gave anti-Semitic ideas a heretofore unseen degree of approval from social scientists. The definition of usury was expanded beyond the limits of the credit business, and in 1893, the Empire's usury law was revised. The debates of the 1880s show how all kinds of economic relations could be made 'legible' as instances of usury.

Two factors fuelled the expansion of the usury debate in the 1880s: the work of credit unions and political anti-Semitism, which was becoming a political force of its own right. The debate was no longer concerned with semi-colonial conditions, but with the established markets of places in the Empire's west and southwest like the Saarland, Rhineland-Palatinate, Baden, Württemberg, and Hessen. Thus, to take an example, a petition from an anti-usury association in

the Saarland hastened the adoption of stricter legislation in $1893 .{ }^{80}$ The focus was on the ways independent farmers in places with partible inheritance ran their farms. According to some 
observers, their parcelled properties inhibited them from developing the foresight of businessmen. The credit unions too held up the ideal of independence. ${ }^{81}$ They grafted notions of rural community onto the market economy and gave them a national scope. They homogenized the practices of their members and at the same time systematized social exclusion. As economic historians have shown, credit unions like the Raiffeisenkassen - which originated in the Rhineland - used the social control they had acquired in the villages to gain an information advantage on the market. ${ }^{82}$ Indeed their precise knowledge of their clientele made it easy for them to sanction delinquent debtors. In this way, the credit unions exploited traditional social relations in order to usher in new economic systematicity.

The other factor, in part related to the credit associations, was anti-Semitic agitation. As a historical study on Kurhessen has shown, Otto Böckel - in 1887 the first political anti-Semite in the Reichstag - was able to mobilize a segment of voters not reached by the existing parties. ${ }^{83}$ Böckel took over a weekly paper that had formerly been called the 'Usury Pill', agitated in writings such as his brochure The Jews, the Kings of Our Time, which saw over 100 editions, and made rural usury the main topic of his racially anti-Semitic, anti-elite politics. ${ }^{84}$ In stark contrast to the high ideal of economic self-sufficiency and the bogeyman of the Jewish 'property butcher', Böckel's constituency was made up of the rural underclasses, people who generally did not own land or cattle. The imaginary victims of the 'property butchers' or cattle dealers, and precisely the people who had the most contact with mortgage creditors and cattle dealers, Jewish and nonJewish alike, namely the independent farmers, were not those who supported the populist antiSemites. The discourse reclaimed a general dichotomy ('productive' vs. 'money grubbing'), but its social locus was specific. This is not to say that landowning farmers did not have anti-Semitic views, but only that a certain political exploitation of this discourse was divorced from the real experiences of farmers with Jewish merchants. ${ }^{85}$ The practical role credit organizations played as a sort of self-help instrument for getting credit went hand in hand with the denigration of Jewish merchants in the press and the pursuit of cases against them in the courts. Anti-usury associations sued merchants and the anti-Semitic press exploited the proceedings. ${ }^{86}$ In this regard, the usury discourse had a violent presence in the countryside; and yet, the dichotomies of this discourse tend to conceal the commonalities between Christians and Jews with respect to trading practices. Historians of the rural economy have uncovered instances of cooperation between Christians and Jews - as well as, for sure, violence against the latter - and have demonstrated that both groups often worked with shared measures of what constituted fair business. ${ }^{87}$ This shows not least in the 
fact that Jewish institutions repeatedly condemned usury. Such sources are difficult to interpret. They might be informed by a strategy seeking to dispel any occasion for allegations against the community, no matter how chimerical. However, there is also evidence that these Jewish responses contain genuine reflections on economic fairness. ${ }^{88}$

The most influential intervention on the topic from the social sciences - the Verein für Socialpolitik's 1887 investigation - sought to put an end to these rural exchange relations. The report, entitled Usury on the Countryside, brought together a broad spectrum of commentators both in respect to academic discipline and political conviction - from 27 different states and provinces in the German Empire. Despite the expanse of the area covered and the authority of the publishers, the report in no way presented 'disinterested' facts that transcended politics, which the Verein otherwise claimed to do. In fact, this was not even its goal, as the controversy about the report's methodology demonstrates. ${ }^{89}$ The Verein had sent a questionnaire to agricultural groups and local governments and evaluated material published by the Prussian State Economic Collegiate [preußisches Land-Ökonomie-Kollegium]. ${ }^{90}$ The report presented hardly a single verifiable case study. The Verein did not do anything to make the discrete pieces of data comparable with one another, and hardly assembled any statistical material. Instead, the publication consisted of a series of stereotyped stories. It repeatedly told of how scheming usurers preyed on unknowing victims. Even though the report's chief editor claimed that explicitly defamatory portions were rewritten, the majority of the reports were defined by anti-Semitic slander. ${ }^{91}$ The statistician Gottlieb Schnapper-Arndt criticized the study's methodology. He first pointed out that statistical material clearly could have been gathered, even if there was no extant data on the frequency of usury per se. In that case, an observable phenomenon could be viewed as a 'symptom' or, in today's parlance, as an indicator of a superordinate yet statistically unobservable phenomenon. ${ }^{92}$ If this method too failed to generate statistical data, then the plausibility of individual cases, controlled for other factors, had to be checked, optimally by gathering contradictory statements from witnesses and submitting them to a 'critique of sources' ${ }^{93}$ Individual cases studied in a controlled fashion, he claimed, did not necessarily have to result in a 'report on popular opinion': 'The enquête itself is not permitted to be opinion. ${ }^{\text {,94 }}$ But the Verein had neglected all of these concerns, Schnapper-Arndt concluded. Instead, and usually without any real evidence to begin with, the report's claims mixed divergent levels in a syncretistic fashion, so that it often was not even clear if the authors themselves found them relevant. Where numbers were given, they were given in undeniably distorted form: for instance, 
in the report on Trier, only those court cases that ended unfavourably for the accused Jewish merchant were listed, or when the accused's confession was reported in the source as Jewish. ${ }^{95}$ Another critic found that the Verein's questionnaire suggested that every form of brokerage was already usury. Thus, the Verein's report was informed by an abstract ideal of a smooth-running, transparent rural market, where the use of information advantages, expertise on market trends, and networks was seen as being superfluous and condemnable. ${ }^{96}$

A Verein representative countered that interviewees' statements about Jews belonged to the 'report on popular opinion' that the Verein planned to produce. Further, he said, the report had, above all, a 'practical' task, not a 'scientific' one. The Verein had only wanted to 'make the public aware of existing damages and suggest ways and means to correct them', for which 'scientific reasoning and quantitative analysis' were 'only necessary to a limited extent'. ${ }^{97}$ Mobilizing antisemitic sentiment and dignifying itself with the garb of the social sciences, this politics was aimed at transforming rural exchange relations. The Verein saw atomized economic subjects who lacked business sense: a problem of overwhelmed economic freedom. ${ }^{98}$ The study's findings fit the rural middle-class politics with which the Verein established itself in the political field in the 1880s. ${ }^{99}$ The suggested improvements ranged from the promotion of institutionalized credit through credit unions, measures against partible inheritance, to the education of the population in order to 'lift the intelligence and character of the farmers' ${ }^{100}$ Thus, the Verein saw the 'civilisational question' ('Kulturfrage') as consisting of 'giving the German farmer some of the self-confidence, skill, and resourcefulness of the American farmer'. ${ }^{101}$ Yet for academic elites, credit unions were more than just instruments of self-help: they were also seen as an instrument of modernization beyond the purview of state subventions. The Verein certainly wanted the state to assist the credit unions, but Gustav Schmoller, founder and central personality of the Verein, was explicit in his statements against direct state involvement in credit. ${ }^{102}$

The usury law of 1880 had regulated monetary credit. In contrast, the expansion of the legal definition of usury in the 1893 law was geared towards regulating all kinds of conversions between the value of things and monetary value. This added urban milieus to the law's sphere. Pawning, along with the buy-back or layaway businesses that were even more common in Germany, were now brought together under the heading 'object and service usury' (Sach- und Leistungswucher). ${ }^{103}$ 'Object usury' was notoriously difficult to define. ${ }^{104}$ Lawmakers and academic experts tried to limit the concept of object usury to a set of clearly outlined exchange relations. They were particularly concerned with building a conceptual firewall against demands 
for higher wages and complaints against landlords that the labour movement might bring up under the rubric of usury. Indeed, the labour movement had a long tradition of thematising usury. ${ }^{105}$ Social democrats agitated with demands for a minimum wage by claiming that employers were exploiting workers' hardship, and they denounced protective tariffs that were opposed to consumers' interests as usury, all without success. ${ }^{106}$ Conversely, in legislative discussions, the semantics of usury and anti-Semitism were deployed against the social democrats. In turn, the social-democratic newspaper Vorwärts viewed the revised usury law as an anti-Semitic 'class law' against small Jewish peddlers, while big industrialists or financiers were by definition never mentioned. ${ }^{107}$ The Junker Kleist-Retzow stated in the Reichstag that if one did not take measures to contain usury, 'socialist cravings' and 'hate against property owners in general' might take hold of the workers. ${ }^{108}$ The economist and social theorist Lorenz von Stein, quoted in the introduction of this article, viewed usury as a social danger because it stirred up 'hatred against capital' and thus 'against the entire economic and social order of all human things'. ${ }^{109}$

Consistent with the circumscribed notion of 'object usury', and in order to keep demands from the social democrats at bay, one economist wrote that usury always had to have a single victim, who had to suffer from exceptional, business-related hardships - mere poverty, hunger, or high rent (the latter was too widespread to qualify as usury) were not sufficient. ${ }^{110}$ In the $1890 \mathrm{~s}$, the concept of usury became precisely delimited: some parts of livelihood fell into the distinct sphere of economy, while others were deemed irrelevant. Usury was seen as an individual, exceptional incongruity within the norms of the objective structure called 'the economy'.

Historians have debated the emergence of the economy as a bounded conceptual entity in history, not the least since Timothy Mitchell put forward the evocative thesis that without distinct scientific and bureaucratic tools that were put to use in the interwar period, no such thing as the 'the economy' existed. ${ }^{111}$ This thesis has been suggestive although contested, and at this point it might be useful to point out different historical nodes at which, by way of intense social conflict, seemingly self-evident spheres like the economy emerged in their objectivity. ${ }^{112}$ With regards to the question of economic subjecthood, the last quarter of the nineteenth century saw such a historical node, and the debates on usury contributed to the respective newly-drawn separation of subject and object. One of the conditions that made defining 'object usury' possible was an emerging knowledge complex that combined administration, philanthropy, and social science. In the 1880s, this complex began to conceive of the economy as a distinct, measurable object of its 
own order. ${ }^{113}$ This was informed by understandings of the economic as an organized system in which certain cycles had their place; a system in which vectorially positioned subjects exchanged with one another in transparent infrastructures; a system in which in-groups were separated from outsiders; a system whose distinct levels were integrated into the national and world economy. ${ }^{114}$

The economy, understood as an objectivized, rule-guided, factually existing system, conditioned the way the subjective aspects of economic activity could play out. As an incongruity defined in relation to individual subjects, usury no longer needed to be hemmed by an objective limit on interest rates, because, according to the running assumption, an economic subject would never sign a contract that was obviously against their own interests. Thus the subjective dimensions of the economic were defined, which usury legislation sought to inscribe into law in the form of protections, common welfare, and the recognition of individual circumstances. Moreover, the law also helped shape an individual, rationally oriented subject. At the same moment, the so-called Austrian school of economics with its theory of marginal utility was conceptualising the economy as a system based on subjective exchanges geared towards maximizing individual benefit. Marginalism for sure has various origins, typically associated with the names of Stanley Jevons from England, Léon Walras from Switzerland, and Carl Menger from Austria. ${ }^{115}$ In the Habsburg empire, Menger and his successors essentially put forward a theory of subjective value; a theory of abstract, subjective exchange. Commentators rushed to demonstrate how usury laws were compatible with this new economic theory. ${ }^{116}$ Isolating a subject that conformed to the natural laws of the economy like the marginalists did provided the guidelines for a civilizing authority that protected backwards, irrational subjects against distortions. ${ }^{117}$

\section{Conclusion}

As one historian studying the usury debates pointed out, 'the First World War marked a watershed' ${ }^{118}$ During the food riots of the war's final years, the 'old' semantics of usury as a set of illegitimate market practices re-emerged. After the war, this semantics was taken up by the movements for consumers' rights and used to express a general concern about social inequalities in a developing welfare state. However, as I have tried to show here, usury denoted something rather different in the late nineteenth century: a discourse of order and a diagnosis of crisis that dramatized certain credit practices and dealt with economic rationality. During the Great 
Depression of the 1870 s, the key political initiative for the passage of new usury legislation came from the right. However, they understood the problem of usury in a way that cohered with widespread assumptions. Most experts taking part in the debate were by no means anti-capitalist, and only a few were romantic-conservative. Defining usury as the exploitation of a deficient economic subject who lacked an understanding of the future consequences of taking on debt fit well with prevailing notions of civilization and education, two key postulates of liberalism. Thus, the new usury laws did not so much mark a turn away from the idea of the market as a regime of truth as they served to restore this idea under the auspices of a state-led remapping of the economic field.

Usury as a diagnosis of crisis gave a platform for experts in the imperial centre to debate questions of power and control. In the encounter between received forms of commensuration and new, rationalized forms, peripheral practices of exchange came to be viewed with suspicion. Further, the problem of usury constituted a site of struggles for political interests and class attitudes towards precarious everyday economic conditions. Agrarian capitalists expressed their fear of the loss of social hierarchy while middle-class reformers such as the Verein für Socialpolitik argued for the integration of more parts of the population into expanding cycles of finance and accumulation. It would be simplifying things to trace the origins of usury as a diagnosis of crisis back to an encounter between the modern market and agricultural economies of subsistence. Rather, the debate revolved around alterable received practices (in which market expansion also played an important role) that modernizers increasingly found inacceptable.

This finding has a larger implication for the history of capitalism as it has been debated among historians lately. Much of the debate is concerned with the dynamics of dis-embedding, and the techniques of re-embedding, of market forces. ${ }^{119}$ Other historians point out the vast spectrum of the commodification of labour in capitalism, and depart from a narrow focus on wage labour to include housework and forced labour. In this essay, I have tried to gesture towards yet another dimension: that is, conflicts over modes of exchange. ${ }^{120}$ The conflicts over modes of exchange, to which the debates on usury and economic rationality testify, did not bring about a singular unfolding logic but ever-new unevenness. Thus, capitalism's work of subsumption placed divergent temporalities in tension with one another and brought clashing forms of commensuration to the fore. ${ }^{121}$ If we retrace how, by the late nineteenth century, a particular conflict over the conceptualisation of exchange became a focal point for politics, this suggests relating both class struggle and epistemic tension to the dynamics of a political framing such as 
economic liberalism in that historical moment. Historians have called liberalism an 'ideology fixed on circulation', and some believe that it was replaced in the years around 1880 by an ideology of national production. ${ }^{122}$ However, if one views usury from an angle of economic rationality, a different picture emerges. In epistemological terms, the concept of the economy denoted a space with its own facticity, an organized system that comprised multiple, yet transparent forces. Anchored in notions of common sense, the juridical definition of usury as exploitation of a subjective lack was founded in the basic assumption that the economic sphere was complex, yet natural, and in principal comprehensible. Such assumptions made exchange into the key problem of economics around 1880. Historians have shown that during late nineteenth-century globalization, economic policy was increasingly conceived of as enmeshed in competing national forces in an international framework. ${ }^{123}$ On a conceptual level, the history of usury as a diagnosis of crisis offers an observation on this process: around 1880, the problem of exchange came to substitute the a priori, unquestioned assumption of circulation. One figuration of this shift was marginalism, which reconceived economic life as abstract subjective exchange. ${ }^{124}$ Another was the question of usury. With the latter, diverse valuation scales and local intermediaries were abolished through a violent discourse of order in the name of a subject that regulated its time and pursued its interests in a calculated, individual, goal-oriented fashion. Pitted against this economic subject was the backward subject of usury, who, according to Lorenz von Stein, lost the 'means of economical calculation' and was consumed by the 'debt that reproduces itself. ${ }^{125}$

\section{Acknowledgements}

I would like to thank Caroline Arni, Geoff Eley, Angelika Strobel, Erika Vause, the editors of Social History (Louise Jackson and Gordon Johnston) and, especially, an anonymous reviewer, for their incisive readings; as well as Börries Kuzmany for crucial archival guidance. I am grateful to the organisers and the participants of the Geschichtskontor, University of Zurich, and the Modern History Colloquium, University of Berne, (both in spring 2015), and of the $8^{\text {th }}$ Critical Finance Studies Conference, University of Southampton (August 2016), for their comments, ideas, and criticism. I would also like to thank the translator, Adam Bresnahan. 


\section{Notes}

${ }^{1}$ A classic text is J. Le Goff, Your Money or Your Life: economy and religion in the middle ages, trans. P. Ranum (New York, 1990 [1986]).

${ }^{2}$ A. Hirschman, The Passions and the Interests: political arguments for capitalism before its Triumph (Princeton, 1977); for a new evaluation see D. Mathiowetz, Appeals to Interest: language, contestation, and the shaping of political agency (University Park PA, 2011).

${ }^{3}$ J. F. Harris, The People Speak! Anti-semitism and emancipation in nineteenth-century Bavaria (Ann Arbor MI, 1994), 133f., 176; J. Bohstedt, The Politics of Provisions: food riots, moral economy, and market transition in England, c. 1550-1850 (Farnham, 2010); M. Gailus, Straße und Brot: Sozialer Protest in den deutschen Staaten unter besonderer Berücksichtigung Preußens, 1847-1849 (Göttingen, 1990); B. Davis, Home Fires Burning: food, politics, and everyday life in World War I Berlin (Chapel Hill NC, 2000).

${ }^{4}$ L. von Stein, Der Wucher und sein Recht: ein Beitrag zum wirthschaftlichen und rechtlichen Leben unserer Zeit (Vienna, 1880), 40.

${ }^{5}$ See, among others, V. Ogle, The Global Transformation of Time 1870-1950 (Cambridge MA, 2015); Q. Slobodian, 'How to see the world economy: statistics, maps, and Schumpeter's camera in the first age of globalization', Journal of Global History, 10, 2 (2015), 307-32; U. Stäheli, Spectacular Speculation: thrills, the economy, and popular discourse (Stanford CA, 2013); C. Davies, 'Papierschwindel und Börsenpanik: Der Gründerkrach von 1873 als Globalisierungsphänomen', Merkur, 66, 12 (2012), 1178-1185; L. Rischbieter, Mikro-Ökonomie der Globalisierung: Kaufleute, Kaffee, Konsumenten im Kaiserreich 1870-1914 (Cologne, 2011); T. Mitchell, Carbon Democracy: political power in the age of oil (London, 2011); A. Preda, Framing Finance: the boundaries of markets and modern capitalism (Chicago, 2009); G. 
Balachandran, 'Power and markets in global finance: the gold standard, 1890-1926', Journal of Global History, 3, 3 (2008), 313-335.

${ }^{6}$ T. Mitchell, Stages of Modernity (Minnesota, 2000), 7; H. Fischer-Tiné, Pidgin Knowledge. Wissen und Kolonialismus (Zurich, 2014), 57.

${ }^{7}$ M. Goswami, Producing India: from colonial economy to national space (Chicago, 2004); R. Birla, Stages of Capital: law, culture, and market governance in late colonial India (Durham NC, 2009).

${ }^{8}$ Geheimes Staatsarchiv Preussischer Kulturbesitz Berlin (GSta), I.HA Rep. 89, no. 27743: Bestimmung des Zinsfusses und Maßregeln gegen den Wucher, Staatsministerium 27 November, 1857.

${ }^{9}$ K. Liebner, Wucher und Staat: Die Theorie des Zinswuchers im Deutschland des 18. und 19. Jahrhunderts (Berlin, 2010), 298f.

${ }^{10}$ C. Braun, M. Wirth, Die Zins Wucher Gesetze, vom Standpunkte der Volkswirthschaft, der Rechtswissenschaft und der legislativen Politik beleuchtet: Ein Wort an die deutschen Gesetzgeber (Mainz, 1856); J. Bentham, Defence of Usury; showing the impolicy of the present legal restraints on the terms of pecuniary bargains (New York, 1787).

${ }^{11}$ A. Smith, An Inquiry into the Nature and Causes of the Wealth of Nations (London, 1776), II.4.15. Smith's argument also informed German opponents of the deregulation of interest. See P. Reichensperger, Gegen die Aufhebung der Zinswuchergesetze (Berlin, 1860), 35.

${ }^{12}$ Österreichisches Staatsarchiv Wien (OeStA), Haus- Hof- und Staatsarchiv (HHStA), SB Nl Lasser 9-3 Wuchergesetz, Votum Finanzminister Karl Ludwig Bruck an Ministerkonferenz 23 and 25 February, 1858.

${ }^{13}$ Davies, op. cit.; M. Grabas, 'Die Ggünderkrise von 1873/79 - Fiktion oder Realität? Einige Überlegungen im Kontext der Weltfinanz- und Wirtschaftskrise von 2008/2009', Jahrbuch für 
Wirtschaftsgeschichte, 52, 1 (2011), 69-95; T. Widmer, Die Schweiz in der Wachstumskrise der 1880er Jahre (Zurich, 1992); H.-U. Wehler, Bismarck und der Imperialismus (Cologne, 1969), 43-111.

14 K. von Lilienthal, 'Die Wuchergesetzgebung in Deutschland unter besonderer Berücksichtigung derselben im preussischen Staate', Jahrbücher für Nationalökonomie und Statistik, new series, 1(1880), 140-61, 366-85, here 367.

${ }^{15}$ K. Th. Eheberg, 'Ueber den gegenwärtigen Stand der Wucherfrage', Jahrbuch für Gesetzgebung, Verwaltung und Volkswirthschaft im Deutschen Reich, 4 (1880), 55-78, here 68.

16 ibid., 67. W. Roscher, System der Volkwirthschaft. Ein Hand- und Lesebuch für Geschäftsmänner und Studierende, Erster Band, die Grundlagen der Nationalökonomie enthaltend, zweite, vermehrte und verbesserte Auflage (Stuttgart and Augsburg, 1857), § 194. On Roscher as the mainstream of German political economy see K. Tribe, Strategies of Economic Order: German economic discourse, 1750-1950 (Cambridge, 1995), 69.

${ }^{17}$ J. Platter, Der Wucher in der Bukowina (Jena, 1878), 32f.

${ }^{18}$ Haus der Abgeordneten, 13. Legislaturperiode, II. Session 1878-79, 29. Sitzung, 19 December 1879, in Stenographische Berichte über die Verhandlungen der durch die Allerhöchste Verordnung vom 3. November 1878 einberufenen beiden Häuser des Landtages: Haus der Abgeordneten, vol. 1 (Berlin, 1879), 719. See O. Sucker, Der Nothstand in Oberschlesien und die Ursachen seiner Entstehung (Breslau, 1880).

${ }^{19}$ Thomas C. Holt, The Problem of Freedom: race, labor, and politics in Jamaica and Britain, 1832-1938 (Baltimore, 1992); B. Naranch and G. Eley (eds), German Colonialism in a Global Age (Durham NC, 2014); A. Zimmerman, Alabama in Africa: Booker T. Washington, the German empire, and the globalization of the new south (Princeton, 2010); S. Conrad, Globalisation and the Nation in Imperial Germany, trans. S. O'Hara (Cambridge, 2010); R. 
Nelson, 'From Manitoba to the Memel: Max Sering, inner colonization and the German east', Social History 35, 4 (2010), 439-57; C. Davis, Colonialism, Antisemitism, and Germans of Jewish Descent in Imperial Germany (Ann Arbor MI, 2012); K. Kopp, Germany's Wild East: constructing Poland as colonial space (Ann Arbor MI, 2012); E. B. Jones, 'The rural "social ladder": internal colonization, Germanization and civilizing missions in the German empire', Geschichte und Gesellschaft, 40 (2014), 457-92.

${ }^{20}$ H. Rosenberg, Große Depression und Bismarckzeit. Wirtschaftsablauf, Gesellschaft und Politik in Mitteleuropa (Berlin [West], 1967). On debate and critique see G. Eley, 'Hans Rosenberg and the great depression of 1873-96: politics and economics in recent German historiography, 196080', in G. Eley, From Unification to Nazism: reinterpreting the German past (Boston, 1986), 2341.

${ }^{21}$ M. Loeffler, 'Das 'Finanzkapital' zur Jahrhundertwende. Der Diskurs in Deutschland und England', in N. Berg (ed.), Kapitalismusdebatten um 1900: Über antisemitisierende Semantiken des Jüdischen (Leipzig, 2011), 115-40; M. Loeffler, 'Producers and parasites: the critique of finance in Germany and Britain, 1873-1933' (D.Phil., University of Chicago, 2012). The foundational text for this thesis is M. Horkheimer and T. W. Adorno, Dialectic of Enlightenment: philosophical fragments, trans. E. Jephcott, (Stanford CA, 2002), 137ff., 'Elements of antisemitism: limits of Enlightenment'.

${ }^{22}$ M. Todorova, 'The trap of backwardness: modernity, temporality, and the study of Eastern European nationalism', Slavic Review 64, 1 (2005), 149.

${ }^{23}$ D. Penslar, Shylock's Children: economics and Jewish identity in modern Europe (Berkeley, 2001), ch. 1.

24 ‘Aus dem Gerichtssaale', Volksblatt für Stadt und Land 20, 16 May, 1872, 13. 
${ }^{25}$ Das Vaterland: Zeitung für die österreichische Monarchie 187, 8 July, 1875, 1; C. Graf von Chorinsky, Der Wucher in Österreich (Vienna, 1877), 1.

26 'Aus dem Gerichtssaale', Die Presse 187, 10 July, 1872, 15; 'Aus dem Gerichtssaale', Neue freie Presse 2768, 9 May, 1872, 8f.; 'Aus dem Gerichtssaale', Neues Fremden-Blatt 127, 9 May, 1872, 4f.; 'Aus dem Gerichtssaale', Volksblatt für Stadt und Land 20, 16 May, 1872, 13; Neue Freie Presse, 2828, 10 July, 1872, morning edition, $6 \mathrm{f}$.

${ }^{27}$ K. E. Franzos, 'Todte Seelen', Neue Freie Presse 3805, 31 March, 1875, morning edition, 1.

${ }^{28}$ Haus der Abgeordneten, 153. Sitzung der 8. Session, 3 December 1875, Stenographische Protokolle über die Sitzungen des Hauses der Abgeordneten des österreichischen Reisrathes, VIII. Session, vol. 5, (Vienna, 1876), 5299. On Rydzowski see F. Adlgasser, Die Mitglieder der österreichischen Zentralparlamente 1848-1918. Konstituierender Reichstag 1848-1849, Reichsrat 1861-1918: Ein biographisches Lexikon - Teilband 2: M-Z (Vienna, 2014), 1054f.

${ }^{29}$ Haus der Abgeordneten, 153. Sitzung der 8. Session, 3 December 1875, 5309.

30 'Oesterreichischer Reichsrath', Neue Freie Presse 4050, 4 December, 1875, morning edition, 1f. Haus der Abgeordneten, 153. Sitzung der 8. Session, 3 December, 1875, 5304.

${ }^{31}$ Nr. 563 der Beilagen zu den stenographischen Protokollen des Abgeordnetenhauses, VIII. Session, Verhandlungen des Hauses der Abgeordneten des österreichischen Reichsrathes in den Jahren 1876-1877, VIII. Session, vol. 7 (Vienna, 1879), 5.

32 Chorinsky, op. cit., 68. OeStA/HHStA SB Nl Lasser 9-3 Wuchergesetz 9.3.4. Verhandlungsunterlagen, Ministerkonferenz zur Diskussion über Abschaffung Wuchergesetze, 23 und 25. February 1858, Votum Finanzminister Karl Ludwig Bruck (quotation).

${ }^{33}$ K. Struve, Bauern und Nation in Galizien: Über Zugehörigkeit und soziale Emanzipation im 19. Jahrhundert (Göttingen, 2005), 385; T. Buchen, Antisemitismus in Galizien. Agitation, Gewalt und politik gegen Juden in der Habsburgmonarchie um 1900 (Berlin, 2012), 41. 
${ }^{34}$ S. Tokarski, Ethnic Conflict and Economic Development: Jews in Galician agriculture 18681915 (Warsaw, 2003), 95, graphic 1.

${ }^{35} 153$. Sitzung der 8. Session, 3. Dezember 1875, 5304.

${ }^{36}$ 154. Sitzung der 8. Session, 4. Dezember 1875, 5334. On Menger see Adlgasser, op. cit., $788 f$.

37 ‘Österreichischer Reichsrath’, Neue Freie Presse 4051, 5 December, 1875, 2f.

${ }^{38} \mathrm{~K}$. Kaps, Ungleiche Entwicklung in Zentraleuropa: Galizien zwischen überregionaler Verflechtung und imperialer Politik (1772-1914) (Vienna, 2015), 390; Tokarski, op. cit., 103.

${ }^{39}$ Kaps, op. cit., 165.

${ }^{40}$ Kaps, op. cit., 201, 453f.

${ }^{41}$ Kaps op. cit., 392 (quotation); Struve, op. cit, 414.

${ }^{42}$ Struve, op. cit., $395-407$.

${ }^{43}$ OE-STA AVA Justizministerium Justiz allgemein I-W2/1 (Post 82-142), box 1863, Vienna, 1 June, 1877 Innenminister an Justizministerium (Aktennotiz des Jusitzministeriums).

${ }^{44}$ See the concise statement made by the justice minister Julius Glaser on 28 April, 1877. 251. Sitzung der 8. Session des Abgeordnetenhauses. See Stenographische Protokolle über die Sitzungen des Hauses der Abgeordneten des österreichischen Reichsrathes, VIII. Session, vol. 8 (Vienna, 1877), 8544.

${ }^{45}$ Deutsches Bundesarchiv Berlin (BAr), R 3001/6246 Reichsgesetz über den Wucher, Finanzministerium Berlin, 6 April, 1880, Den Wucher in Oberschlesien betreffend.

${ }^{46}$ BAr R 3001/6246, Reichsgesetz über den Wucher 1880, Landrat des Kreises Neustadt, 13 February, 1880.

${ }^{47}$ GSta I. HA Rep. 151 C, Nr. 9324, Regierungspräsidium Oppeln, 17 February, 1880, quoting the Landrat of the Kreis Ratibor. 
${ }^{48}$ Stenographische Berichte der Verhandlungen des Reichstages, 5. Sitzung, 4. Periode, II. Session, vol. 4, Berlin 1879, 749.

${ }^{49}$ See, for example, C. v. Thüngen-Rossbach, Die Wucher- und Wechselfrage: Vortrag (Berlin, 1879).

${ }^{50}$ M. H. Geyer, 'Defining the common good and social justice: popular and legal concepts of 'Wucher' in Germany from the 1860s to the 1920s', in W. Steinmetz (ed.), Private Law and Social Inequality in the Industrial Age: comparing legal cultures in Britain, France, Germany, and the United States (New York, 2000), 457-83. This tactic was also commented on by the contemporaneous press. See, for instance, BAr R 3001/6251, Äusserungen der Presse zur Wucherfrage, November 1878-January 1893, 'Der Antrag Reichensperger', in Volks-Zeitung 57, 1. Bl., without date, clipping from 17 March, 1879.

${ }^{51}$ H. Geffcken, 'Zur Wucherfrage III', in Allgemeine conservative Monatsschrift für das christliche Abendland 36, 1 (1879), 120-30, 121.

${ }^{52}$ The remark was made by the Centre politician Paul Reichensperger at the $30^{\text {th }}$ session, 31 March 1879. Stenographische Berichte der Verhandlunges des Reichstages, 4. Legislaturperiode, II. Session, vol. 1 (Berlin, 1879), 744. For this reason, the proposal also found adherents in the liberal press. See BAr R 3001/6251, Äusserungen der Presse zur Wucherfrage, November 1878Januar 1893; 'Der neue Wuchergesetz-Antrag', Kölnische Zeitung 74, 1. B1. 15, March 1879, 1; Börsen Courier 153, no date, clipping from 4 April, 1879; Frankfurter Zeitung 92, 1 April, 1879, morning edition, 1 .

${ }^{53}$ On the historical context of the protective tariffs see Geyer, op. cit., 464.

${ }^{54}$ G. Schmoller, 'Die öffentlichen Leihhäuser, sowie das Pfandleih- und Rückkaufgeschäft überhaupt: ein Beitrag zur Lehre von der Zins- und Gewerbefreiheit und von den öffentlichen 
Unternehmungen', Jahrbuch für Gesetzgebung, Verwaltung und Volkswirthschaft im Deutschen Reich 4 (1880), 87-124, 123.

${ }^{55}$ See, for instance, Germania 200, appendix, 1 September, 1879; [Emil Richter], Germanicus, Juden und Junker. Eine Beleuchtung des Spieler- und Wucherer-Processes in Hannover (Leipzig, no date [1893]).

${ }^{56}$ BAR R 3001/6245, Brief des Kriegsministeriums an Reichskanzler Bismarck, Berlin, 7 March, 1879; see also F. Krause, Der Wucher und seine Geldleute: Ein Zeitbild, $3^{\text {rd }}$ ed. (Berlin, 1894).

${ }^{57}$ On honour and social relations in the German Empire see A. Goldberg, Honor, Politics and the Law in Imperial Germany, 1870-1914 (Cambridge, 2010); U. Frevert, Ehrenmänner: Das Duell in der bürgerlichen Gesellschaft (Munich, 1991).

${ }^{58}$ Kaps, op. cit.

${ }^{59}$ I borrow the term 'valuation scales' from J. Guyer, Marginal Gains: monetary transactions in Atlantic Africa (Chicago, 2004), 21.

${ }^{60}$ L. von Caro, Der Wucher: Eine socialpolitische Studie (Leipzig, 1893), 188. Analogous customs were also present in the German Empire. See Anon, Die Agitation im Eisenacher Oberland gegen den Wucher. Von einem Bauernfreund im Eisenacher Oberlande (Berlin, 1878), $6 f$.

${ }^{61}$ Caro, op. cit., 186.

${ }^{62}$ OeSTA AVA Justizministerium Justiz Allgemein I-W2/1, Post 335 (box 1866), Städt. Bezirksgericht Lemberg an das Oberlandesgericht Lemberg, (undated, before 15 October 1890). Chorinsky, op. cit., 100; Caro, op. cit., 152.

${ }^{63}$ On the politics of commensuration see W. N. Espeland and M. L. Stevens, 'Commensuration as a social process', Annual Review of Sociology, 24 (1998), 313-43. 
${ }^{64}$ F. Otto, 'Antiliberale und antisemitische Angriffe auf die Reichswährungs-Institutionen im Zeichen der Gründerkrise. Zum Problem der politischen Diskussionskultur im Kaiserreiche', Zeitschrift für Geschichtswissenschaft 49 (2001), 485-97, 488f. See also F. Otto, 'Der Diskurs um die deutsche Währungsvereinheitlichung im 19. Jahrhundert: Die Konstruktion der Ideologie des nationalen Geldes', Jahrbuch für Wirtschaftsgeschichte, 45, 1 (2004), 197-219.

${ }^{65}$ BAr R3001/6246 Reichsgesetz über den Wucher 1880, Landrat des Kreises Neustadt, 13 February, 1880 .

${ }^{66}$ T. Zahra, 'Travel agents on trial: policing mobility in east central Europe, 1889-1989', Past and Present, 223 (2014), 161-93.

${ }^{67}$ OE-STA AVA Justizministerium Justiz allgemein I-W2/1 (Post 82-142), box 1863, case no. 121 report from 3 May 1876.

${ }^{68}$ BAr R3001/6246 Reichsgesetz über den Wucher 1880, anonymous, no date.

${ }^{69}$ The anthropologist Jane Guyer coined the metaphor of a 'coral reef' of formalities that exist side by side. Guyer, op. cit., 159.

${ }^{70}$ Caro, op. cit., S. 258.

${ }^{71}$ OE-STA AVA Justiz allgemein I-W2/1 (Post 143-210) box 1864 (1848-1917), No. 203: Falkenstein, 10 February, 1879: Petition an Reichsrat, von Gemeinde Falkenstein in Polen und 12 weiteren Gemeinden. For Upper Silesia, see also GSta I. HA Rep. 151 C, Nr. 9324 Lublinitz, Amtsrichter Brandenburg, Ottmachau, 16 February, 1880 as well as multiple complaints from Bavaria in BAr R 3001/6247 Wuchergesetz 1880ff., Königlich Bayrisches Staatsministerium des K. Hauses und des Äusseren, Munich 23 January, 1889, 'Ergebnis der Erhebungen über Wucher auf dem Lande', 28.

${ }^{72}$ G.F. Dasbach, Der Wucher im trierischen Lande (Trier, 1887), $18 \mathrm{f}$. 
${ }^{73}$ E. Barre, Der ländliche Wucher: Ein Beitrag zur Wucherfrage bezüglich der Vorschläge des Deutschen Volkswirthschaftsraths zur Bekämpfung des ländlichen Wuchers (Berlin, 1890), 16.

${ }^{74}$ BAr R 3001/6247 Wuchergesetz 1880ff., Auszug aus den Berichten der Verwaltungsbehörden über den Wucher auf dem Lande und die Mittel seiner gesetzlichen Abhülfe (1890), Aussage des Landrats zu Schlüchtern (Hessen); Barre, op. cit., 15; Anon, Der Wucher im Regierungsbezirk Trier und die landwirthschaftliche Bank in Trier (Trier, 1885), 4.

${ }^{75}$ Barre, op. cit., 12.

${ }^{76}$ I rely here, as throughout the article, on $\mathrm{H}$. W. Smith, 'The discourse of usury: relations between Christians and Jews in the German countryside, 1880-1914', Central European History 32 (1999) 255-279, an article that provides a superb model to interpret the debates on usury. See also A. Binnenkade, KontaktZonen: Jüdisch-christlicher Alltag in Lengnau (Cologne, 2009).

${ }^{77}$ The legislative discussion followed the Galician example. See 'Betrieb von Geld- und Betreibungsgeschäften', in Amtliche Sammlung der Gesetze und Verordnungen des eidgenössischen Standes Solothurn, LXVIII, 1876-1880 (Solothurn, no date); Verhandlungen des Kantonsrathes von Solothurn 1878 (Solothurn, no date), 94-101.

${ }^{78}$ E. Brenner, 'Der Wucher und seine Bekämpfung', Schweizerische Zeitschrift für Gemeinnützigkeit 20 (1881), 197-213; J.L. Weibel, 'Die rechtliche Behandlung des Wuchers', Verhandlungen des schweizerischen Juristenvereins 1884, 1. Heft (Basel, 1884).

${ }^{79} \mathrm{~K}$. von Lilienthal, 'Der Wucher auf dem Lande', Zeitschrift für die gesamte Strafrechtswissenschaft 8 (1888), 157-221, $157 \mathrm{ff}$.

${ }^{80}$ Anon, Petition des Vereins gegen den Wucher im Saargebiet an den deutschen Reichstag in Berlin, November 1887 (no place, no date). 
${ }^{81}$ On the educational function attributed to the credit unions, see, for example, Verhandlungen der am 28. und 19. September 1888 in Frankfurt a.M. abgehaltenen Generalversammlung des Vereins für Socialpolitik über den ländlichen Wucher [...], (Leipzig, 1889), 111.

${ }^{82}$ F. Schlütz, Ländlicher Kredit: Kreditgenossenschaften in der Rheinprovinz (1889-1914) (Stuttgart, 2013); T. W. Guinnane, 'Cooperatives as information machines: German rural credit cooperatives, 1883-1914', Journal of Economic History 63, 2 (2001), 366-89.

${ }^{83}$ R. Peal, 'Anti-Semitism and rural transformation in Kurhessen: the rise and fall of the Böckel movement' (D.Phil., Columbia University, 1985), 140.

${ }^{84}$ O. Böckel, Die Juden, Könige unserer Zeit. Rede [...] gehalten in der öffentlichen Versammlung des Deutschen Antisemiten-Bundes auf der Bockbrauerei zu Berlin am 4. Oktober $1886,25^{\text {th }}$ ed. (Marburg, 1887); H. Berkessel, 'Antisemitische Presse in einer ländlichen Region. Die Mainzer Wochenzeitung 'Die Wucherpille' (1882-1886)', in Gideon Botsch et al. (eds), Politik des Hasses: Antisemitismus und radikale Rechte in Europa (Hildesheim, 2010), 29-42; Peal, op. cit., 101.

${ }^{85}$ See Smith, op. cit., 265; Peal, op. cit., 233.

${ }^{86}$ Verein gegen den Wucher im Saargebiet, Bericht über die Thätigkeit des Vereins im Jahre 1887, erstattet durch den Schriftführer Herrn Olzem (no place, no date), 7; GSta VI. HA Nl Adolf Stoecker, no. 892; [Ph. Klausner], Prozeß gegen die jüdischen Wucherer Markus Löb von Mainz und Hirsch Süßer von Würzburg: Geführt gegen Löb von der Strafkammer zu Mainz am 14., 15. und 16. Februar 1883, und gegen Süßer vor der Strafkammer zu Würzburg am 15., 16. und 17. Februar (Mannheim, no date). On the anti-Semitic publications of the Paulinusblatt see O. Blaschke, Katholizismus und Antisemitismus im Deutschen Kaiserreich (Göttingen, 1997), 87. ${ }^{87}$ Peal, op. cit.; Smith, op. cit.; M. Richarz, 'Die soziale Stellung der jüdischen Händler auf dem Lande am Beispiel Südwestdeutschlands', in W. E. Mosse (ed.), Jüdische Unternehmer in 
Deutschland im 19. und 20. Jahrhundert (Stuttgart, 1992), 271-283; Binnenkade, op. cit., chap. 5; Struve, op. cit., 417; S. Bennewitz, Basler Juden, französische Bürger. Migration und Alltag einer jüdischen Gemeinde im frühen 19. Jahrhundert (Basel, 2008), 330-59.

${ }^{88}$ F.X. Helmdörffer, Politik und Wucher der Juden: Zu den Schriften W. Marr's (Freiburg i. Br., 1879); Hat das Judenthum dem Wucherunwesen Vorschub geleistet? Flugblatt, herausgegeben vom deutsch-israelitischen Gemeindebunde (Leipzig, 1879). Also contained in BAr R 3001/6251, Äusserungen der Presse zur Wucherfrage, November 1878-January 1893, Schlesische Presse 446, no date, clipping from 5 July, 1879, 1f. There is a reference to a Jewish group 'against the nuisance of usury' in Börsen-Courier, 16 August, 1884, 1. See also Smith, op. cit., $271 \mathrm{f}$.

89 '[Review] Der Wucher auf dem Lande', Vierteljahrschrift für Volkswirtschaft, Politik und Kulturgeschichte, 24, 4 (1887), 239-59; G. Schnapper-Arndt, Zur Methodologie sozialer Enquêten mit besonderem Hinblick auf die neuerlichen Erhebungen über den Wucher auf dem Lande (Frankfurt a.M., 1888); J. Zuns, Der Wucher auf dem Lande: Eine Kritik des Fragebogens (Frankfurt a.M., 1888). After the revision of the usury law in 1893, the controversy was taken up by the press again. See BAr R 3001/6252, Äusserungen der Presse zur Wucherfrage, Jan. 1893June 1919, L. v. Bar, 'Der Gesetzesentwurf über den Wucher', Der Zeitgeist! Beiblatt zum Berliner Tageblatt, 27 March, 1893.

${ }^{90}$ Verein für Socialpolitik, Wucher auf dem Lande, VIII.

${ }^{91}$ H. Thiel, 'Korreferat über die Wucherfrage und die Frage der ländlichen Kreditorganisation', in Verein für Socialpolitik, Verhandlungen, 41-64, 44.

${ }^{92}$ G. Schnapper-Arndt, op. cit., 7.

${ }^{93}$ Schnapper-Arndt, op. cit., 26.

${ }^{94}$ Schnapper-Arndt, op. cit., 10, 11.

${ }^{95}$ Schnapper-Arndt, op. cit., $9,42 \mathrm{f}$. 
${ }^{96}$ Zuns, op. cit., esp. 13-16.

${ }^{97}$ Thiel, op. cit., 45. For a further defense of the report, see J. Platter, 'Der Wucher und die Bauern in Deutschland (1888)', in idem, Kritische Beiträge zur Erkenntnis unserer socialen Zustände und Theorien (Basel, 1894), 395-423.

${ }^{98}$ Striking are the Verhandlungen $1888,110$.

${ }^{99}$ E. Grimmer-Solem, The Rise of Historical Economics and Social Reform in Germany, 18641894 (Oxford, 2003), 223ff. On the middle-class politics in the empire's east see Jones, op. cit.

${ }^{100}$ Wucher auf dem Lande, Report on Württemberg.

${ }^{101}$ Verhandlungen 1888, S. 19. On the Verein's orientation toward American policies see Zimmerman, Alabama in Africa.

${ }^{102}$ Grimmer-Solem, op. cit., 232f.

${ }^{103}$ In contrast to pawning, one sold an item of value to a buyback merchant with the option of buying it back later at a higher price. Buyback merchants in Berlin resisted being classified and regulated as pawn dealers. See BAR R 3001/6245 Neuer Verein der Berliner Rückkaufshändler, Druckschrift 22. März 1879: 'Ein Wort über den Unterschied zwischen Rückkauf und Wucher'. On the frequency of the use of buyback merchants see GSta I. HA Rep. 90A Nr. 1669: Akten betreffend das Pfandleihgewerbe, Votum Innenminister, Berlin 27 January, 1879. See also K. C. Führer, 'Pawning in German working-class life before the First World War', International Review of Social History 46 (2001), 29-44.

${ }^{104}$ On objections against the expansion of the concept's definition see, for example, Vossische Zeitung, 12 March, 1893; National-Zeitung, 10 March, 1893; Der Zeitgeist! Beiblatt zum Berliner Tageblatt, 27 March, 1893 (with the German Chamber of Commerce's criticism of the expansion).

105 Th. Welskopp, Das Banner der Brüderlichkeit: die deutsche Sozialdemokratie vom Vormärz 
bis zum Sozialistengesetz (Bonn, 2000), 622-39.

${ }^{106}$ Geyer, op. cit., 471f. BAr R 3001/6252, Äusserungen der Presse zur Wucherfrage, Jan. 1893June 1919, ‘Der Kommissionsbericht über die Wuchervorlage', Vorwärts, 16. September 1893. ${ }^{107}$ Geyer, op. cit., 472. 'Der Kommissionsbericht über die Wuchervorlage', Vorwärts, 16 September 1893.

108 30. Sitzung, 31 March, 1879, Stenographische Berichte der Verhandlungen des Reichstages, 4. Legislaturperiode, II. Session, vol. 1 (Berlin, 1879), 750.

${ }^{109}$ von Stein, op. cit., $126 f$.

${ }^{110}$ W. Lexis, 'Wucher', in J. Conrad et al. (eds), Handwörterbuch der Staatswissenschaften (Jena, 1895), 777, 779.

${ }^{111}$ T. Mitchell, Rules of Experts: Egypt, Techno-Politics, Modernity (Berkeley, 2002).

${ }^{112}$ See M. Suter, 'Das Wissen der Schulden: Recht, Kulturtechnik und Alltagserfahrung im liberalen Kapitalism', Berichte zur Wissenschaftsgeschichte, 37, 2 (2014), 148-164.

${ }^{113}$ The Europe-wide debates on the minimum wage and the legal regulation of wage labour are striking examples. See D. Simmons, Vital Minimum: need, science, and politics in modern France (Chicago, 2015); T. Wobbe, 'Making up people: Berufsstatistische Klassifikation, geschlechtliche Kategorisierung und wirtschaftliche Inklusion um 1900 in Deutschland', Zeitschrift für Soziologie, 41, 1 (2012), 41-57; C. Topalov, Naissance du chômeur 1880-1910 (Paris, 1994); S. Conrad, E. Macamo, and B. Zimmermann, 'Die Kodifizierung der Arbeit: Individuum, Gesellschaft, Nation', in J. Kocka (ed.), Geschichte und Zukunft der Arbeit (Frankfurt a.M., 2000), 449-76.

${ }^{114}$ On the latter point, see Q. Slobodian, op. cit.

${ }^{115}$ The extent to which the Austrian school was marginalist is a matter of debate. Only the second generation of the Austrian school gathered around this term, yet marginalist considerations do 
already appear in Menger's foundational work. See Erich Streissler, 'To what extent was the Austrian school marginalist?', in R.D. Collison Black et al. (eds), The Marginal Revolution in Economics: interpretation and evaluation (Durham NC, 1973), 160-176. C. Menger, Grundsätze der Volkswirthschaftslehre: Erster, allgemeiner Theil (Vienna, 1871).

${ }^{116}$ H. von Schullern zu Schrattenhofen, Die Beseitigung des Bestiftungszwanges und der Wuchergesetze (Vienna, 1899); C. Scheimpflug, Referat betreffend den Wucher im modernen Geldwesen und Geldverkehr, Leo-Gesellschaft in Wien: Section für Socialwissenschaften 1892 (Wien, 1892).

${ }^{117}$ See Streissler, op. cit..

${ }^{118}$ Here and in the following Geyer, op. cit., 474-83, 460 for quotation. This observation draws on a detailed case study of German society during the First World War and the hyperinflation in the Weimar Republic. See M. H. Geyer, Verkehrte Welt. Revolution, Inflation und Moderne: München 1914-1924 (Göttingen, 1998).

${ }^{119}$ For a sophisticated account of the dis-embedding/re-embedding thesis, arguing that the commodification of risk provided a distinctly capitalist way of re-embedding, see J. Levy, Freaks of Fortune: The Emerging World of Capitalism and Risk in Nineteenth-Century Amercia (Cambridge MA, 2012).

${ }^{120}$ R. Spang, Stuff and Money in the Time of the French Revolution (Cambridge MA, 2015), especially 273; J. Sklansky, 'Labor, money, and the financial turn in the history of capitalism', Labor: Studies in Working-Class History of the Americas 11, 1 (2014), 23-46.

${ }^{121}$ H. Harootunian, Marx after Marx: history and time in the expansion of capitalism (New York, 2015).

${ }^{122}$ G. Hanloser, Krise und Antisemitismus. Eine Geschichte in drei Stationen von der Gründerzeit über die Weltwirtschaftskrise bis heute (Münster, 2004), 49. 
${ }^{123}$ Conrad, op. cit.; Cornelius Torp, Die Herausforderung der Globalisierung: Wirtschaft und Politik in Deutschland 1860-1914 (Göttingen, 2005), 148.

${ }^{124} \mathrm{~K}$. Tribe, 'Continental political economy from the physiocrats to the marginal revolution', in T. M. Porter et al. (eds), The Cambridge History of Science, Vol. 7: the Modern Social Sciences (Cambridge, 2003), 154-70, 154.

${ }^{125}$ von Stein, op. cit., 40. 